\title{
Solvent extraction effects on phytochemical constituents profiles, antioxidant and antimicrobial activities and functional group analysis of Ecballium elaterium seeds and peels fruits
}

\author{
Samir FELHI ${ }^{1}$, Amal DAOUD ${ }^{1}$, Hafedh HAJLAOUI ${ }^{2}$, Kais MNAFGUI ${ }^{1}$, Néji GHARSALLAH ${ }^{1}$, Adel KADRI ${ }^{1,3 *}$
}

\begin{abstract}
Ecballium elaterium is a perennial herb with multiple medicinal properties. It was widely used in folk medicine as cathartic, anti-inflammatory and analgesic agents. The present study was devoted to investigate the effect of diethyl ether, acetone, and methanol solvent on the extraction, phytochemicals profiles, antioxidant and antimicrobial activities of Ecballium elaterium seeds and peels fruits. The total phenolic, flavonoid, flavonol, condensed tannins and carotenoids contents were estimated. Maximum phenolic (107 $\pm 4 \mathrm{mg} \mathrm{GAE} / \mathrm{g})$ and flavonoid (18 $\pm 0 \mathrm{mg} \mathrm{QE} / \mathrm{g})$ contents were also found in the methanol peels fruits extract. Results showed that methanol peels fruits extract have the highest antioxidant activity with $\mathrm{IC}_{50}$ values of $1.2 \pm 0.1$ and $1 \pm 0 \mathrm{mg} / \mathrm{mL}$ for DPPH and ABTS, respectively, and $\mathrm{EC}_{50}$ value of $1040 \pm 5 \mathrm{mg} / \mathrm{mL}$ for reducing power assays. Acetone and diethyl ether peels fruits extracts showed the best antibacterial agents especially against Micrococcus luteus, however no antifungal activity was observed. Spectral data of FT-IR analysis of Ecballium elaterium seeds and peels fruits extracts revealed the presence of functional groups such as $-\mathrm{OH}, \mathrm{C}-\mathrm{H}, \mathrm{C}-\mathrm{O}$ and $\mathrm{C}=\mathrm{O}$. Due to their high antioxidant and antibacterial activities, E. elaterium seeds and peels fruits extracts have promising potential as future natural antioxidant and antibacterial agents in food industry.
\end{abstract}

Keywords: Ecballium elaterium; solvent effects; phytochemical contents; antioxidant and antimicrobial properties; FT-IR analysis.

Practical Application: Ecballium elaterium seeds and peels fruits can be potentially used as natural antioxidant and antibacterial inhibitor.

\section{Introduction}

Ecballium elaterium is an important medicinal plant belonging to the family of Cucurbitaceae. It has been known in Tunisia as 'Feggous elhemir', traditionally consumed as food in infusion, mixture of fruit or even in aerosol in cases of fever or flu (Bizid et al., 2014) and used as natural remedy with therapeutic activities against a wide range of aliment's pathogens (Boukef, 1986). The fruit juice of this species has traditionally been used in the treatment of acute and chronic jaundice, rhinosinusitis, and sinusuitis (Salhab, 2013; Sargin et al., 2013). The extract of its roots and fruit has been used as a remedy. This plant is considered rich in proteins, lipids, cucurbitacins (B, D, E, I and L,) and cucurbitacin derivatives such as glycosylcucurbitacins and triterpenoids glycosides (Greige-Gerges et al., 2007). Moreover, extracts of the fruit are still used in Mediterranean region in different medicinal system (Latté, 2009). Several recent studies have revealed that the extracts of E. elaterium contain a wide range of active ingredients such as phenolic compounds, flavonoids, alkaloids, sterols, amino acids, vitamins, tocopherols, and fatty acids justifying their usage in food systems (Abbassi et al., 2014; Touihri et al., 2015). It was frequently used in the treatment of various health disorders and diseases including sinusitis (Sargin et al., 2013), rhinosinusitis (Mazokopakis et al., 2009), antimicrobial (Abbassi et al., 2014), anti-inflammatory
(El-Gengaihi et al., 2009), cytotoxic (Sasmakov et al., 2012), and anticancer activities (Touihri et al., 2015).

The aims of this study were to investigate the effect of three solvents (diethyl ether, acetone, and methanol) on phytochemical contents of E. elaterium seeds and peels fruits extracts by maceration method at room temperature and then to evaluate their effect on antioxidant properties by DPPH, ABTS radical scavenging activities and ferric reducing power assay. Also, the antimicrobial activity of the extracts against some pathogenic bacteria and fungi was investigated. FT-IR spectral analysis was used as analytical tool to characterize various active functional groups presents in the different extracts.

\section{Materials and methods}

\subsection{Chemicals and reagents}

The chemical reagents namely Folin-Ciocalteu reagent, Trolox (6-hydroxy-2,5,7,8-tetramethylchroman-2-carboxylic acid), DPPH (1,1-Diphenyl-2-picrylhydrazyl), potassium ferrocyanide $\left(\mathrm{K}_{3} \mathrm{Fe}(\mathrm{CN})_{6}\right)$, ABTS (2,2'-azinobis (3-ethylbenzothiazoline-6sulfonic acid)), ferric chloride $\left(\mathrm{FeCl}_{3}\right)$, quercetin, ascorbic acid, BHT (butylatedhydroxytoluene), catechin, vanillin, $\beta$-carotene, 
aluminium chloride $\left(\mathrm{AlCl}_{3}\right)$, TCA (trichloroacetic acid), diethyl ether, acetone, ethanol, cyclohexane, and methanol were purchased from Sigma-Aldrich (USA). All chemicals and solvents were of the analytical grade.

\subsection{Preparation of extracts}

E. elaterium were collected in June 2013 from the north area of Tunisia, precisely from the Cap-Bon $\left(10^{\circ} 44^{\prime} \mathrm{E}, 36^{\circ} 27^{\prime} \mathrm{N}\right)$ region. The seeds and peels fruits of the plant were separated, and were rinsed with distilled water, then oven-dried for $48 \mathrm{~h}$ at $60{ }^{\circ} \mathrm{C}$, and ground to a fine powder using a mill. The powdered material was stored at $+4^{\circ} \mathrm{C}$ until further use. The extracts were obtained by maceration of dry plant material $(50 \mathrm{~g})$ with diethyl ether, acetone, and methanol ( $300 \mathrm{~mL} \times 2$, each solvent) for $48 \mathrm{~h}$ at room temperature with continuous agitation. The ratio used in the extraction process was $1 / 12(\mathrm{~m} / \mathrm{v})(1 \mathrm{~g}$ sample with $12 \mathrm{~mL}$ of solvent). Extract solutions were filtered with filter paper and then collected and concentrated using a rotary evaporator at $35-55^{\circ} \mathrm{C}$. The yield of dried extracts was calculated according to the following Equation 1:

$$
\text { Yield }(\%)=\left(W_{1} \times 100\right) / W_{2}
$$

Where $\mathrm{W}_{1}$ was the weight of extract after evaporation of solvent and $\mathrm{W}_{2}$ was the dry weight of the sample.

\subsection{Determination of total phenolic, total flavonoid, condensed tannin, flavonols and carotenoids contents}

The phytochemical contents of extracts were determined as described by Bakari et al. (2015). The total phenolic was assessed using Folin-Ciocalteu reagent. The absorbance was measured at $760 \mathrm{~nm}$ using a spectrophotometer (Bio-Rad SmartSpecTM plus), and the results were expressed as $\mathrm{mg}$ of gallic acid equivalents (GAE) per gram of extract (mg GAE/g). The flavonoid content was determined using aluminum chloride colorimetric method and expressed as mg of quercetin equivalents $(\mathrm{QE})$ per gram of extract ( $\mathrm{mg} \mathrm{QE} / \mathrm{g}$ ). The condensed tannin content was analyzed by using the modified vanillin assay described by Sun et al. (1998). The results were expressed as $\mathrm{mg}$ of catechin equivalents (CE) per gram of extract $(\mathrm{mg} \mathrm{CE} / \mathrm{g})$. The content of flavonols was performed according to the method described by Abdel-Hameed (2009) with some modifications where quercetin was used to make the calibration curve. Briefly, $1 \mathrm{~mL}$ of $2 \%$ aluminum chloride and $3 \mathrm{~mL}$ of $5 \%$ sodium acetate were added to $1 \mathrm{~mL}$ of each extract. The absorbance of samples was measured after $2.5 \mathrm{~h}$ at $440 \mathrm{~nm}$. The results were expressed as $\mathrm{mg}$ of quercetin equivalents $(\mathrm{QE})$ per gram of extract $(\mathrm{mg} \mathrm{QE} / \mathrm{g})$. The carotenoids content was determined according to method described by Talcott \& Howard (1999). A standard calibration curve was plotted using $\beta$-carotene. The results were expressed as $\beta$-carotene equivalents $(\beta$-carotene $E)$ per gram of extract ( $\mu \mathrm{g} \beta$-carotene $\mathrm{E} / \mathrm{g})$.

\subsection{Antioxidant activity}

DPPH free radical scavenging and Ferric Reducing Antioxidant Power (FRAP) assay

All these tests were determined by spectrophotometric method based on the method described by Kadri et al. (2011).

\section{ABTS free radical scavenging activity}

The radical scavenging activity using ABTS radical was carried out according to Re et al. (1999) with a modification. Trolox was used as a reference antioxidant and the radical scavenging activity was expressed by $\mathrm{IC}_{50}$ value calculated denote the concentration required to scavenge $50 \%$ of ABTS radical.

\subsection{Antimicrobial activity}

The antimicrobial activity of seeds and peels fruits extracts were tested against a large panel of microorganisms by means of agar-well diffusion assay. Bacteria and fungi were obtained from international culture collections (ATCC). They included five Gram-positive bacteria: Staphylococcus aureus ATCC 6538, Listeria monocytogenes, Bacillus cereus JN 934390, Bacillus subtilis JN 934392 and Micrococcus luteus and three Gram-negative bacteria: Escherichia coli ATCC 25922, Klebsiella pneumonia and Salmonella enteritidis. The fungal strains were also tested: Fusarium phyllophilum AB587006, Penicillium sp., Fusarium oxysporum AB586994, Pythium catenulatum AY598675, Fusarium sp. JX391934. The minimum inhibitory concentration (MIC) and minimum bactericidal concentration (MBC) were based on the same protocol as displayed by Daoud et al. (2015).

\subsection{Fourier Transform Infrared Spectroscopy (FT-IR) spectra analysis}

FT-IR spectra of extracts were recorded at room temperature on a Universal ATR Sampling Accessory infrared spectrophotometer. Dried paste of extracts were loaded on the sample chamber of FT-IR spectrophotometer at room temperature $\left(25 \pm 2^{\circ} \mathrm{C}\right)$ with a scan range from 550 to $4000 \mathrm{~cm}^{-1}$ at a resolution of $4 \mathrm{~cm}^{-1}$.

\subsection{Statistical analysis}

All data were expressed as mean \pm standard deviation (SD) of triplicate measurements. Statistical analyses of the data were performed using the SPSS version 17.0 software (SPSS Inc., Chicago, IL, USA). The results were analyzed by one-way analysis of variance (ANOVA) followed by Tukey test for multiple comparisons. Differences were considered significant at $\mathrm{p}<0.05$.

\section{Results and discussion}

\subsection{Extraction yield}

The yield of crude extracts from the seeds and peels fruits of E. elaterium, obtained by maceration method using different type of solvents, were calculated and the results were shown in Table 1 . The recovery percentage of extractable compounds of seeds and peels fruits are ranged from $8 \pm 0$ to $14 \pm 2 \%$ and $1 \pm 0$ to $11 \pm 1 \%$ (w/w), respectively. The results revealed that the highest yield extracts were obtained by the diethyl ether $(14 \pm 2 \%)$ and methanol $(11 \pm 1 \%)$ for seeds and peels fruits extracts, respectively. Significant differences were observed among extraction yields obtaining by methanol compared to other solvents in seeds and peels fruits $(\mathrm{p}<0.05)$. This difference may be attributable to the higher solubility of extractable bioactive components such as carbohydrates and proteins in methanol 
than in diethyl ether and acetone. The variation in the yields of extracts could be attributed to the difference in solvent polarities used witch also plays a key role in increasing the solubility of phytochemical compounds (Silva et al., 2014; Naima et al., 2015). Differences in the structure of phytochemical compounds also determine their solubility in solvents of different polarity (Felhi et al., 2016a). In fact, three solvents with different polarity were used, and they can be arranged as follows (starting from more low dielectric constant values): diethyl ether (4.3) < acetone (20.7) < methanol (32.7) (Maryott \& Smith, 1951). This change appear to be related not only to the difference in the polarity of extracts of the components but also to the solvents used, which also plays a vital role in increasing the solubility of phytochemical compounds.

Therefore, this result confirmed the effect of solvent extraction and the plant organ on the yield extraction and consequently confirms the richness of this plant in polar substances.

\subsection{Effect of extracting solvent on the phytochemical contents of the various extract}

The solubility of the phenolic compounds was mostly influenced by the nature of solvent used and their polarity. As known, methanol is polar protic solvent, while acetone and diethyl ether are polar and non-polar aprotic solvents,

Table 1. Extract yield of seeds and peels fruits of E. elaterium.

\begin{tabular}{lccc}
\hline \multirow{2}{*}{$\begin{array}{c}\text { Part of } \\
\text { plant } \backslash \text { Solvent }\end{array}$} & \multicolumn{3}{c}{ Extract yield \% (w/w) } \\
\cline { 2 - 4 } Seeds & Diethyl ether & Acetone & Methanol \\
Peels fruits & $14 \pm 2^{\mathrm{a}, \mathrm{x}}$ & $9 \pm 1^{\mathrm{b}, \mathrm{x}}$ & $8 \pm 0^{\mathrm{c}, \mathrm{y}}$ \\
\hline Values are averages \pm standard deviation of triplicate analysis. For each solvent of \\
seeds extracts, values in the same row for each test followed by a different letter $(\mathrm{a-c})$ \\
are significantly different $(\mathrm{p}<0.05)$. Results are ranked in ascending order; $\mathrm{a}>\mathrm{b}>\mathrm{c}$. \\
For each solvent of peels fruits extracts, values in the same row for each test followed by \\
a different letter (d-f) are significantly different $(\mathrm{p}<0.05)$. Results are ranked in ascending \\
order; $\mathrm{d}>\mathrm{e}>\mathrm{f}$. For each plant organ, values in same column for each test followed \\
by a different letter $(\mathrm{x}, \mathrm{y})$ are significantly different $(\mathrm{p}<0.05)$. Results are ranked in \\
ascending order; $\mathrm{x}>\mathrm{y}$.
\end{tabular}

respectively. The recovery of phytochemical from plant could possibly be influenced by dielectric constant, chemical structure of organic solvents, and as well as chemical properties of plant phytochemical. The amount of total phenolic content (TPC), total flavonoid content (TFC), flavonols, condensed tannins and carotenoids contents of seeds and peels fruits extracts from E. elaterium were given in Table 2. The results showed variations in the levels of TPC, TFC, flavonols, condensed tannins, and carotenoids contents of all extracts. As shown, the TPC content varied from $19 \pm 3$ to $107 \pm 4 \mathrm{mg} \mathrm{GAE} / \mathrm{g}$ and the highest amount was obtained with methanol followed by acetone for both seeds and peels fruits. The lower content of phenolic compounds in acetone extract compared to methanol may be explained by the low solubility of polyphenols in this solvent thanks to bonds hydrogen force between polyphenols and proteins (Sripad et al., 1982). For TFC, the lowest value was obtained for acetone extract in seeds. This means that this plant contains more flavonoid heterosides than aglicones. Similar trend was found for flavonol contents. For condensed tannins, the highest levels were found in methanol extracts $(39 \pm 2 \mathrm{mg} \mathrm{CE} / \mathrm{g})$ for seeds and $(21 \pm 1 \mathrm{mg} \mathrm{CE} / \mathrm{g})$ for peels fruits. The relationships between tannins contents and extraction solvents can be related to the polymerization degree for the tannins extracted by different solvents (Naima et al., 2015). The interactive abilities of solvent and tannins compounds are probably related to chemical compositions and structures. The solubility of the tannins is correlated to the degree of polymerization due to the increase in the number of hydroxyl groups - $\mathrm{OH}$. However, for carotenoid content, the highest levels were found in methanol extract $(229 \pm 1 \mu \mathrm{g} \beta$-carotene $\mathrm{E} / \mathrm{g})$ for seeds, and in acetone extract $(291 \pm 1 \mu \mathrm{g} \beta$-carotene $\mathrm{E} / \mathrm{g})$ for peels fruits. In general, the solubility of phenolic compounds is not only dependent on the type of solvent used but also on the degree of polymerization and interaction of phenolics with other phytochemical, vitamins, and minerals (Naczk \& Shahidi, 2004). According to the data reported by El-Haci \& Bekkara (2011) the levels of polyphenols of methanol-water $(7: 3, \mathrm{v} / \mathrm{v})$ leaves and stems E. elaterium extracts varied from $48 \pm 8 \mathrm{mg} \mathrm{GAE} / \mathrm{g}$ and $11 \pm 1 \mathrm{mg} \mathrm{GAE} / \mathrm{g}$, respectively. Abbassi et al. (2014) reported that the TPC of methanol-water $(8: 2, \mathrm{v} / \mathrm{v})$ fruits, leaves, flowers and

Table 2. Total phenolic, total flavonoid, flavonols, condensed tannins, and carotenoids contents in the different solvents extract of seeds and peels fruits extracts of E. elaterium.

\begin{tabular}{|c|c|c|c|c|c|c|}
\hline \multirow{2}{*}{$\begin{array}{c}\text { Solvent } \\
\text { Part of plant }\end{array}$} & \multicolumn{2}{|c|}{ Diethyl ether } & \multicolumn{2}{|c|}{ Acetone } & \multicolumn{2}{|c|}{ Methanol } \\
\hline & Seeds & Peels fruits & Seeds & Peels fruits & Seeds & Peels fruits \\
\hline $\begin{array}{l}\text { Total phenolic content } \\
\text { (mg GAE/g) }\end{array}$ & $19 \pm 3^{c, x}$ & $21 \pm 2^{f, x}$ & $34 \pm 1^{b, y}$ & $44 \pm 1^{e, x}$ & $69 \pm 1^{a, y}$ & $107 \pm 4^{\mathrm{d}, \mathrm{x}}$ \\
\hline $\begin{array}{l}\text { Total flavonoid content } \\
(\mathrm{mg} \mathrm{QE} / \mathrm{g})\end{array}$ & $2 \pm 0^{b, y}$ & $8 \pm 1^{f, x}$ & $2 \pm 1^{b, y}$ & $9 \pm 0^{e, x}$ & $17 \pm 0^{a, y}$ & $18 \pm 0^{\mathrm{d}, \mathrm{x}}$ \\
\hline $\begin{array}{l}\text { Flavonols content } \\
\text { (mg QE/g) }\end{array}$ & $0.2 \pm 0^{\text {b,y }}$ & $4 \pm 1^{e, x}$ & $0.5 \pm 0^{\text {b,y }}$ & $6 \pm 1^{\mathrm{d}, e, \mathrm{x}}$ & $11 \pm 1^{a, x}$ & $8 \pm 3^{\mathrm{d}, \mathrm{x}}$ \\
\hline $\begin{array}{l}\text { Condensed tannins } \\
\text { content (mg CE/g) }\end{array}$ & $1 \pm 0^{\mathrm{b}, \mathrm{x}}$ & $3 \pm 2^{e, x}$ & $1 \pm 0^{\mathrm{b}, \mathrm{y}}$ & $2 \pm 2^{e, x}$ & $39 \pm 2^{a, x}$ & $21 \pm 1^{\mathrm{d}, \mathrm{y}}$ \\
\hline $\begin{array}{l}\text { Carotenoids content } \\
(\mu \mathrm{g} \beta \text {-carotene } \mathrm{E} / \mathrm{g})\end{array}$ & $9 \pm 3^{c, y}$ & $279 \pm 1^{e, x}$ & $143 \pm 0^{b, y}$ & $291 \pm 1^{\mathrm{d}, \mathrm{x}}$ & $229 \pm 1^{a, y}$ & $246 \pm 1^{\mathrm{f}, \mathrm{x}}$ \\
\hline
\end{tabular}

Values are averages \pm standard deviation of triplicate analysis. For each solvent of seeds extracts, values in the same row for each test followed by a different letter (a-c) are significantly different $(\mathrm{p}<0.05)$. Results are ranked in ascending order; $\mathrm{a}>\mathrm{b}>\mathrm{c}$. For each solvent of peels fruits extracts, values in the same row for each test followed by a different letter $(\mathrm{d}-\mathrm{f})$ are significantly different $(\mathrm{p}<0.05)$. Results are ranked in ascending order; $\mathrm{d}>\mathrm{e}>\mathrm{f}$. For each plant organ, values in same row for each test followed by a different letter $(\mathrm{x}, \mathrm{y})$ are significantly different $(\mathrm{p}<0.05)$. Results are ranked in ascending order; $\mathrm{x}>\mathrm{y}$. 
roots extracts of the plant varied from $7 \pm 1$ to $47 \pm 3 \mathrm{mg} \mathrm{GAE} / \mathrm{g}$, the TFC varied from $2 \pm 0$ to $17 \pm 2 \mathrm{mg} \mathrm{CE} / \mathrm{g}$ and tannins content varied from $2 \pm 0$ to $4 \pm 0 \mathrm{mg}$ GAE/g. Touihri et al. (2015) reported that the chemical composition of the seed oil of plant are rich in unsaturated fatty acids (linoleic acid, punicic acid, oleic acid, palmitic acid and myristic acid), Tocopherols ( $\gamma$ - and $\delta$-tocopherols) and phytosterols ( $\beta$-sitosterol and campestérol). These compounds have more affinity with diethyl ether. For the main compounds present in the peels fruits, no studies were carried out until now in the literature.

The results presented in this work confirmed that methanol was the best solvent to extract phytochemicals compounds such as phenolic compounds, flavonoids, flavonols, tannins and carotenoids. It should be pointed too that there is a significant difference between phytochemical contents of the different extracts and the plant part used $(\mathrm{p}<0.05)$. Therefore, the E. elaterium extracts demonstrated that the solubility of phytochemicals compounds is not only dependent on the type of solvent used but also on the plant part. Phytochemical constituents have been reported to be associated with antioxidative action in biological systems. In light of the obtained results, E. elaterium seeds and peels fruits are a good source of phytochemical compounds such as phenolics, flavonoids and tannins that could be used in foods, cosmetics or pharmaceutical products.

\subsection{Effect of extracting solvent on the antioxidant activities}

DPPH radical scavenging activity: DPPH is a stable radical assay based on the theory that a hydrogen donor is an antioxidant, gives reducing capacity and measures compounds that are radical scavengers (Suárez-Jiménez et al., 2015). It was one of the most widely used methods for screening the antioxidant activity of vegetable materials and plant extract (Sahu et al., 2013). As shown in Figure 1a, the DPPH scavenging ability of seeds and peels fruits extracts increased in a concentration dependent manner. The values were ranged from 51.1 to $55.3 \%$ and from 59.4 to $82.5 \%$ for seeds and peels fruits extract, respectively. The DPPH free radical scavenging activity was also evaluated by $\mathrm{IC}_{50}$ and the results were depicted in Table 3 . The highest radical scavenging activity was obtained in methanol $(2 \pm 0$ and $1.2 \pm 0.1 \mathrm{mg} / \mathrm{mL})$ followed by acetone $(2.5 \pm 0.0$ and $1.5 \pm 0.0 \mathrm{mg} / \mathrm{mL})$ for seeds and peels fruits, respectively. However, ascorbic acid $(0.2 \pm 0.0 \mathrm{mg} / \mathrm{mL})$ and BHT $(0.4 \pm 0.0 \mathrm{mg} / \mathrm{mL})$ exhibited higher antioxidant activity than all E. elaterium seeds and peels fruits extracts.

ABTS free radical scavenging activity: The ABTS radical known as nitrogen-centered synthetic radical is an excellent tool for determining the antioxidant activity of hydrogen-donating antioxidants and of chain-breaking antioxidant. The results presented in Figure 1b exhibited interesting radical-scavenging activity towards the ABTS radical with scavenging activity was concentration dependent and ranging from 53.1 to $72.6 \%$. The $\mathrm{IC}_{50}$ values of extracts given in Table 3 . The highest ABTS radical scavenging activity was found in methanol and acetone peels fruits extracts with $\mathrm{IC}_{50}$ values of $1 \pm 0$ and $1.1 \pm 0.1 \mathrm{mg} / \mathrm{mL}$, respectively, followed by methanol seeds extract with $\mathrm{IC}_{50}$ of $1.4 \pm 0.0 \mathrm{mg} / \mathrm{mL}$, while the lower scavenging activity was determined with diethyl ether extracts. This test indicated that all extracts exhibited lower levels of scavenging activity compared to the reference antioxidant Trolox with $\mathrm{IC}_{50}$ value of $0.2 \pm 0.0 \mathrm{mg} / \mathrm{mL}$. The ABTS radical scavenging activities of seeds and peels fruits extracts
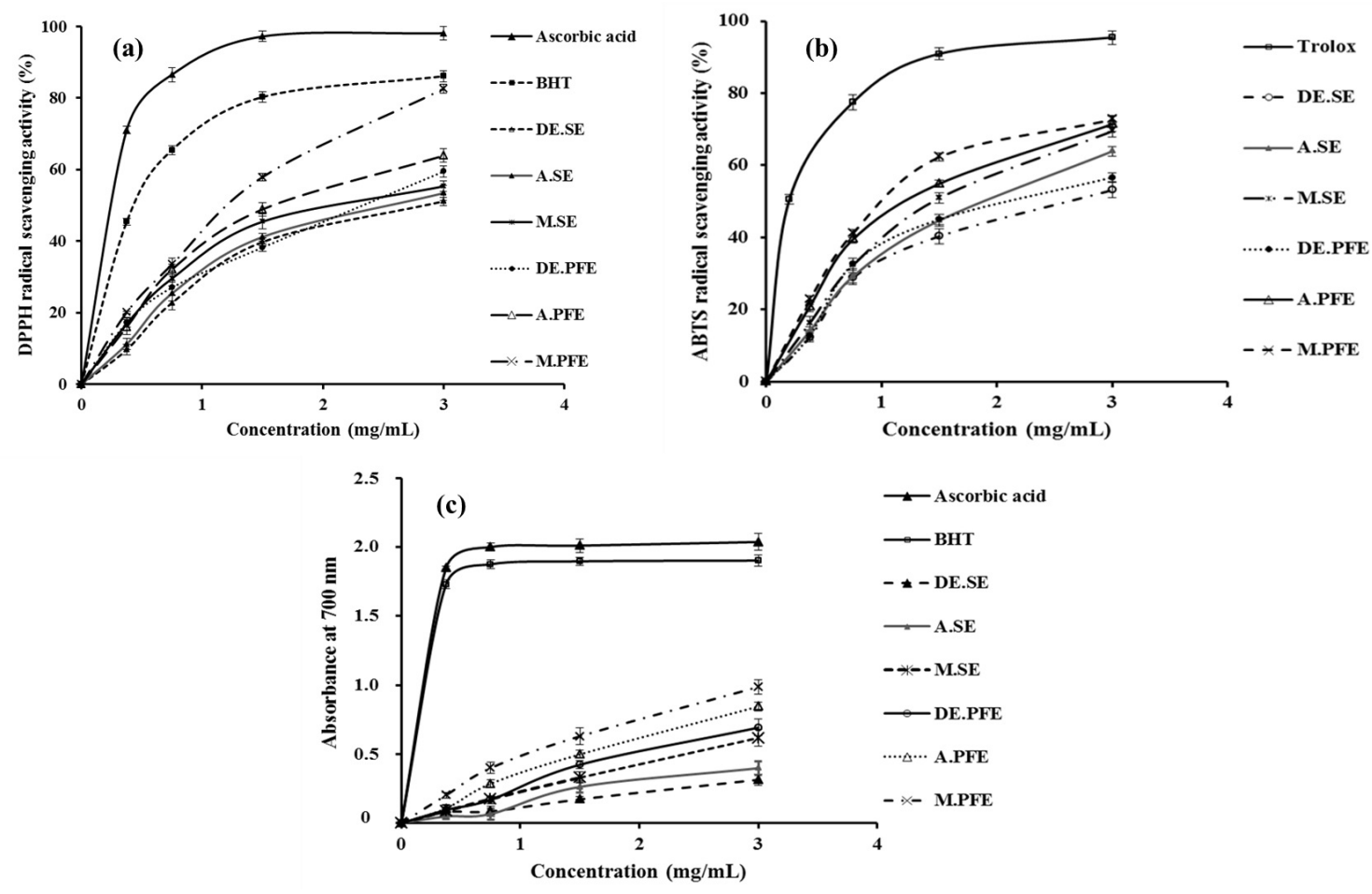

Figure 1. The antioxidant activities of extracts of E. elaterium. DPPH radical scavenging activity (a), ABTS radical scavenging activity (b) and reducing power assay (c). DE.SE: Diethyl ether seeds extract; A.SE: Acetone seeds extract; M.SE: Methanol seeds extract; DE.PFE: Diethyl ether peels fruits extract; A.PFE: Acetone peels fruits extract; M.PFE: Methanol peels fruits extract. All data are expressed as mean \pm SD. 
Table 3. DPPH, ABTS and reducing power assay of seeds and peels fruits extracts of E. elaterium.

\begin{tabular}{|c|c|c|c|c|c|c|}
\hline \multirow[t]{2}{*}{ Solvent } & \multicolumn{2}{|c|}{$\mathrm{DPPH} \mathrm{IC}_{50}(\mathrm{mg} / \mathrm{mL})$} & \multicolumn{2}{|c|}{$\mathrm{ABTS} \mathrm{IC}_{50}(\mathrm{mg} / \mathrm{mL})$} & \multicolumn{2}{|c|}{ Ferric Reducing power $\mathrm{EC}_{50}(\mu \mathrm{g} / \mathrm{mL})$} \\
\hline & Seeds & Peels fruits & Seeds & Peels fruits & Seeds & Peels fruits \\
\hline Diethyl ether & $2.7 \pm 0.0^{\mathrm{a}, \mathrm{x}}$ & $2.3 \pm 0.0^{\mathrm{d}, \mathrm{y}}$ & $2.6 \pm 0.2^{\mathrm{a}, \mathrm{x}}$ & $2.2 \pm 0.0^{\mathrm{d}, \mathrm{y}}$ & n.d & $1800 \pm 6^{\mathrm{d}}$ \\
\hline Acetone & $2.5 \pm 0.0^{\mathrm{b}, \mathrm{x}}$ & $1.5 \pm 0.0^{\mathrm{e}, \mathrm{y}}$ & $1.8 \pm 0.1^{\mathrm{b}, \mathrm{x}}$ & $1.1 \pm 0.1^{e, y}$ & n.d & $1520 \pm 5^{\mathrm{e}}$ \\
\hline Methanol & $2 \pm 0^{c, x}$ & $1.2 \pm 0.1^{\mathrm{f}, \mathrm{y}}$ & $1.4 \pm 0.0^{c, x}$ & $1 \pm 0^{\mathrm{f}, \mathrm{y}}$ & $2430 \pm 5^{x}$ & $1040 \pm 5^{\mathrm{f}, \mathrm{y}}$ \\
\hline Ascorbic acid & \multicolumn{2}{|c|}{$0.2 \pm 0.0$} & \multicolumn{2}{|c|}{ n.t } & \multicolumn{2}{|c|}{$92 \pm 2$} \\
\hline BHT & \multicolumn{2}{|c|}{$0.4 \pm 0.0$} & \multicolumn{2}{|c|}{ n.t } & \multicolumn{2}{|c|}{$104 \pm 3$} \\
\hline Trolox & \multicolumn{2}{|c|}{ n.t } & \multicolumn{2}{|c|}{$0.2 \pm 0.0$} & \multicolumn{2}{|c|}{ n.t } \\
\hline
\end{tabular}

Values are averages \pm standard deviation of triplicate analysis. For each solvent of seeds extracts, values in the same column followed by a different letter (a-c) are significantly different $(\mathrm{p}<0.05)$. Results are ranked in ascending order; $\mathrm{a}>\mathrm{b}>\mathrm{c}$. For each solvent of peels fruits extracts, values in the same column followed by a different letter $(\mathrm{d}-\mathrm{f})$ are significantly different $(p<0.05)$. Results are ranked in ascending order; $d>e>f$. For each plant organ, values in same row followed by a different letter $(x, y)$ are significantly different $(p<0.05)$. Results are ranked in ascending order; $\mathrm{x}>\mathrm{y}$. n.d: not determined. n.t: not tested.

are in the order: methanol>acetone>diethyl ether. Methanol solvent extract exhibiting greater TPC, also depicted good ABTS radical scavenging activity in this study. Therefore, ABTS radical scavenging potential is very much associated with their TPC.

Ferric reducing power assay: The ferric reducing power assay measure the transformation of $\mathrm{Fe}^{3+} /$ ferricyanide complex into $\mathrm{Fe}^{2+}$ by donating an electron. The results illustrated in Figure $1 \mathrm{c}$ exhibited dose-dependent manners. The best reducing power activity of peels fruits extract was determined in methanol with $\mathrm{EC}_{50}$ values of $1040 \pm 5 \mu \mathrm{g} / \mathrm{mL}$, followed by acetone $\left(\mathrm{EC}_{50}=1520 \pm 5 \mu \mathrm{g} / \mathrm{mL}\right.$ ) (Table 3 ). The $\mathrm{EC}_{50}$ of all extracts were higher than those of ascorbic acid and BHT. El-Haci \& Bekkara (2011) studied the reducing power of leaves of E. elaterium and noted that ethyl acetate fraction presented more activity to reduce the iron relative to $n$-butanol fraction.

The antioxidant activity of the extracts was strongly dependent on the extraction solvent (Arakaki et al., 2016). The choice of extraction solvent is a crucial step for the assessment of antioxidant activity of extracts, since polarity of solvents determines the recovery of natural antioxidants from herbals (Goulas et al., 2012; Galanakis et al., 2013). These findings were supported by previous studies on Paramignya trimera (L.) (Nguyen et al., 2015), Opuntia ficus-indica (L.) (Ammar et al., 2015), Solanum melongena (L.) (Boulekbache-Makhlouf et al., 2013) and Myrtus communis (L.) (Amensour et al., 2010), which reported that extracts prepared by methanol solvent had higher antioxidant properties than other organic solvents used. Results of the current investigation show that acetone and diethyl ether extracts exhibited lower levels of antioxidant activity. Acetone is capable to provide high antioxidant activity due to its hydrogen-bonding ability, which is crucial for the extraction of antioxidant phenolic compounds (Rodríguez-Rojo et al., 2012). The efficiency of methanol was related to its intermediate polarity, which allows it to solvate low molecular weight organics compounds possessing protonatable functional groups such as $\mathrm{COOH}$ and $\mathrm{OH}$ (Augusto et al., 2014; Nguyen et al., 2015). These functional groups were strongly responsible for a good antioxidant activity. In this study, it appears that methanol extract possess a strong hydrogen donating capabilities to act as antioxidant. The variation in the reducing power assay of seeds and peels fruits extracts was strongly affected by the extraction solvents. A good correlation was found between total phenolic contents of the different extract and DPPH $\left(\mathrm{R}^{2}=0.85\right)$ ABTS
$\left(R^{2}=0.84\right)$ and reducing power assays $\left(R^{2}=0.38\right)$, and between $\mathrm{DPPH}$ and ABTS $\left(\mathrm{R}^{2}=0.94\right)$, and DPPH and reducing power methods $\left(\mathrm{R}^{2}=0.73\right)$, however, a poorly correlation was found between ABTS and reducing power $(\mathrm{R}=0.45)$. Hence, our findings suggests that the antioxidant activity of E. elaterium extracts might be exerted by the phenolic compounds in the plant and its antioxidant properties is related to its richness in phenolic compounds which acts as good electron donors and could terminate the radical chain reaction by converting free radicals to more stable products. These results showed that E. elaterium seeds and peels fruits could be a potential natural source of antioxidants that can be used in food and nutraceutical applications.

\subsection{Effect of extracting solvent on the antimicrobial activity}

The antimicrobial activities of seeds and peels fruits extracts were performed using agar-well diffusion assay. Results reported in Table 4 showed variations in antimicrobial activity of E. elaterium seeds and peels fruits extracts. In the seeds, diethyl ether and acetone extracts were more effective against $S$. aureus, with an inhibition zone diameter of $15 \pm 1$ and $14 \pm 1 \mathrm{~mm}$, respectively, while the other bacteria showed moderate sensitivity toward the tested extracts with inhibition zone diameter ranging from $8 \pm 0$ to $12 \pm 1 \mathrm{~mm}$. Among the peels fruits, the acetone extract showed a strong antibacterial against $L$. monocytogenes, B. cereus, $B$. subtilis, $M$. luteus and $E$. coli with inhibition zones diameter of $22 \pm 2,18 \pm 1,18 \pm 1,18 \pm 1,16 \pm 1 \mathrm{~mm}$, respectively. In the same way, the diethyl ether extract showed an interesting activity against $B$. subtilis and $M$. luteus with inhibition zone diameter of $17 \pm 2$ and $17 \pm 1 \mathrm{~mm}$, respectively. A lower antibacterial activity was observed in methanol extract against all tested strains. Sasmakov et al. (2012) reported that methanol extract of E. elaterium had slight activity against S. aureus (ATCC 29213) with inhibition zone diameter of $8 \pm 0 \mathrm{~mm}$, and negative activity against B. subtilis (ATCC 6059) and E. coli (ATCC 25922), which are different as compared to our values for methanol extract. Generally, the E. elaterium peels fruits extracts showed strong antibacterial effect on the tested isolates compared to the seeds extracts. The evaluation of the antifungal activity of seeds and peels fruits extracts against fungal strains revealed that all extracts were not active. The absence of antifungal activity is probably due to the presence of active ingredient in E. elaterium extract in very low quantities, which needed the use of large 
amounts of crude extract and also may suggest that the extracts of E. elaterium may act in an indirect way; the active ingredient may exist as a precursor, which requires activation in the body by in vivo unknown mechanism.

The MIC and MBC values of the seeds and peels fruits extracts of E. elaterium are summarized in Table 5. The MIC and $\mathrm{MBC}$ values for tested bacterial strains were in the range of $2 \pm 1-50 \pm 4 \mathrm{mg} / \mathrm{mL}$ and $12 \pm 2-100 \pm 4 \mathrm{mg} / \mathrm{mL}$, respectively. The diethyl ether and acetone peels fruits extracts showed the strongest activity against $M$. luteus with values of MIC $2 \pm 1 \mathrm{mg} / \mathrm{mL}$ and MBC $12 \pm 2$ and $25 \pm 2 \mathrm{mg} / \mathrm{mL}$ respectively. Furthermore, $S$. aureus appeared the most sensitive microorganisms tested for acetone seeds extract with MIC value of $3 \pm 1 \mathrm{mg} / \mathrm{mL}$ and MBC value $25 \pm 2 \mathrm{mg} / \mathrm{mL}$. In this study, the Gram-negative isolates were less resistant to the plant extracts than the Gram-positive bacterial isolates. The higher resistance of Gram-negative bacteria could be accredited to the complexity of the double membrane including cell envelope, that be expressed by lipoprotein and lipopolysaccharide, and which plays the role of a barrier to the antibacterial substances, contrasted to the single membrane structure of Gram-positive bacteria (Zarai et al., 2012; Janakat et al., 2015).

Table 4. Antibacterial and antifungal activities of seeds and peels fruits extracts of E. elaterium.

\begin{tabular}{|c|c|c|c|c|c|c|c|c|}
\hline \multicolumn{9}{|c|}{ Inhibition zone diameter $(\mathrm{mm})$} \\
\hline Microorganisms & \multicolumn{2}{|c|}{ Diethyl ether } & \multicolumn{2}{|c|}{ Acetone } & \multicolumn{2}{|c|}{ Methanol } & \multicolumn{2}{|c|}{ Antibiotics } \\
\hline Bacteria & Seeds & Peels fruits & Seeds & Peels fruits & Seeds & Peels fruits & Chloram. & Cyclo. \\
\hline \multicolumn{9}{|l|}{ Gram-positive } \\
\hline S. aureus & $15 \pm 1^{\mathrm{a}, \mathrm{x}}$ & $12 \pm 1^{\mathrm{e}, \mathrm{y}}$ & $14 \pm 1^{\mathrm{a}, \mathrm{x}}$ & $15 \pm 2^{\mathrm{d}, \mathrm{x}}$ & - & - & $16 \pm 0$ & n.t \\
\hline L. monocytogenes & - & $15 \pm 1^{\mathrm{e}}$ & $12 \pm 1^{\mathrm{a}, \mathrm{y}}$ & $22 \pm 2^{\mathrm{d}, \mathrm{x}}$ & $8 \pm 1^{b}$ & - & $12 \pm 0$ & n.t \\
\hline B. cereus & $8 \pm 0^{\mathrm{a}, \mathrm{y}}$ & $16 \pm 1^{\mathrm{d}, \mathrm{x}}$ & $9 \pm 2^{\mathrm{a}, \mathrm{y}}$ & $18 \pm 1^{\mathrm{d}, \mathrm{x}}$ & $9 \pm 1^{\mathrm{a}, \mathrm{x}}$ & $10 \pm 2^{\mathrm{e}, \mathrm{x}}$ & $26 \pm 1$ & n.t \\
\hline B. subtilis & $8 \pm 1^{\mathrm{a}, \mathrm{y}}$ & $17 \pm 2^{\mathrm{d}, \mathrm{x}}$ & $9 \pm 2^{a, y}$ & $18 \pm 1^{\mathrm{d}, \mathrm{x}}$ & $9 \pm 1^{\mathrm{a}, \mathrm{x}}$ & $11 \pm 2^{\mathrm{e}, \mathrm{x}}$ & $24 \pm 0$ & n.t \\
\hline M. luteus & $10 \pm 1^{\mathrm{a}, \mathrm{y}}$ & $17 \pm 1^{\mathrm{d}, \mathrm{x}}$ & $9 \pm 1^{\mathrm{a}, \mathrm{y}}$ & $18 \pm 1^{\mathrm{d}, \mathrm{x}}$ & $9 \pm 2^{\mathrm{a}, \mathrm{x}}$ & $9 \pm 0^{\mathrm{e}, \mathrm{x}}$ & $20 \pm 2$ & n.t \\
\hline \multicolumn{9}{|l|}{ Gram-negative } \\
\hline E. coli & $8 \pm 1^{\mathrm{a}, \mathrm{y}}$ & $14 \pm 1^{\mathrm{e}, \mathrm{x}}$ & $9 \pm 1^{\mathrm{a}, \mathrm{y}}$ & $16 \pm 1^{\mathrm{d}, \mathrm{x}}$ & $10 \pm 1^{\mathrm{a}, \mathrm{x}}$ & $11 \pm 2^{\mathrm{f}, \mathrm{x}}$ & $23 \pm 0$ & n.t \\
\hline K. pneumoniae & $8 \pm 0^{\mathrm{a}}$ & - & $8 \pm 1^{\mathrm{a}}$ & - & - & - & $22 \pm 1$ & n.t \\
\hline S. enteritidis & - & $11 \pm 1^{\mathrm{d}}$ & - & $12 \pm 2^{\mathrm{d}}$ & - & - & $16 \pm 0$ & n.t \\
\hline \multicolumn{9}{|l|}{ Fungi } \\
\hline Fusarium phyllophilum & - & - & - & - & - & - & n.t & $14 \pm 0$ \\
\hline Penicillium sp & - & - & - & - & - & - & n.t & $14 \pm 1$ \\
\hline Fusarium oxysporum & - & - & - & - & - & - & n.t & $20 \pm 2$ \\
\hline Pythium catenulatum & - & - & - & - & - & - & n.t & $17 \pm 1$ \\
\hline Fusarium sp. & - & - & - & - & - & - & n.t & $18 \pm 2$ \\
\hline
\end{tabular}

Values are mean \pm standard deviation of three separate experiments. For each solvent of seeds extracts, values in the same row followed by a different letter (a-c) are significantly different $(\mathrm{p}<0.05)$. Results are ranked in ascending order; $\mathrm{a}>\mathrm{b}>\mathrm{c}$. For each solvent of peels fruits extracts, values in the same row followed by a different letter $(\mathrm{d}-\mathrm{f})$ are significantly different $(\mathrm{p}<0.05)$. Results are ranked in ascending order; $\mathrm{d}>\mathrm{e}>\mathrm{f}$. For each plant organ, values in same row followed by a different letter $(\mathrm{x}, \mathrm{y})$ are significantly different $(\mathrm{p}<0.05)$. Results are ranked in ascending order; $\mathrm{x}>\mathrm{y}$. Chloram.-Chloramphenicol (15 $\mu \mathrm{g} /$ well) and Cyclo.-Cycloheximide (20 $\mu \mathrm{g} /$ well) were used as standards. (-): no antimicrobial activity. n.t: not tested.

Table 5. MIC and MBC value of seeds and peels fruits extracts of E. elaterium.

\begin{tabular}{|c|c|c|c|c|c|c|c|c|c|c|c|c|}
\hline \multirow{3}{*}{$\begin{array}{c}\text { Solvent } \\
\text { Part of plant } \\
\text { Bacterial strains }\end{array}$} & \multicolumn{4}{|c|}{ Diethyl ether } & \multicolumn{4}{|c|}{ Acetone } & \multicolumn{4}{|c|}{ Methanol } \\
\hline & \multicolumn{2}{|c|}{ Seeds } & \multicolumn{2}{|c|}{ Peels fruits } & \multicolumn{2}{|c|}{ Seeds } & \multicolumn{2}{|c|}{ Peels fruits } & \multicolumn{2}{|c|}{ Seeds } & \multicolumn{2}{|c|}{ Peels fruits } \\
\hline & $\mathrm{MIC}$ & $\mathrm{MBC}$ & $\mathrm{MIC}$ & $\mathrm{MBC}$ & MIC & $\mathrm{MBC}$ & $\mathrm{MIC}$ & $\mathrm{MBC}$ & $\mathrm{MIC}$ & $\mathrm{MBC}$ & $\mathrm{MIC}$ & $\mathrm{MBC}$ \\
\hline \multicolumn{13}{|l|}{ Gram-positive } \\
\hline S. aureus & $6 \pm 2^{\mathrm{a}, \mathrm{x}}$ & $25 \pm 4^{\mathrm{A}, \mathrm{X}}$ & $6 \pm 1^{\mathrm{d}, \mathrm{x}}$ & $12 \pm 2^{\mathrm{D}, \mathrm{Y}}$ & $3 \pm 1^{\mathrm{b}, \mathrm{y}}$ & $25 \pm 2^{\mathrm{A}, \mathrm{X}}$ & $6 \pm 1^{\mathrm{d}, \mathrm{x}}$ & $12 \pm 1^{\mathrm{D}, \mathrm{Y}}$ & - & - & - & - \\
\hline L. monocytogenes & - & - & $6 \pm 2^{\mathrm{d}}$ & $25 \pm 2^{\mathrm{D}}$ & $50 \pm 4^{\mathrm{a}, \mathrm{x}}$ & $100 \pm 2^{\mathrm{A}, \mathrm{X}}$ & $6 \pm 1^{\mathrm{d}, y}$ & $12 \pm 1^{\mathrm{E}, \mathrm{Y}}$ & $12 \pm 2^{\mathrm{b}}$ & $25 \pm 2^{\mathrm{B}}$ & - & - \\
\hline B. cereus & $25 \pm 2^{\mathrm{a}, \mathrm{x}}$ & $100 \pm 2^{\mathrm{A}, \mathrm{X}}$ & $6 \pm 1^{\mathrm{f}, \mathrm{y}}$ & $12 \pm 1^{\mathrm{FY}}$ & $6 \pm 2^{\mathrm{b}, \mathrm{y}}$ & $50 \pm 2^{\mathrm{B}, \mathrm{X}}$ & $12 \pm 1^{\mathrm{e}, \mathrm{x}}$ & $25 \pm 2^{\mathrm{E}, \mathrm{Y}}$ & $3 \pm 2^{\mathrm{cy}}$ & $50 \pm 2^{\mathrm{B}, \mathrm{Y}}$ & $50 \pm 1^{\mathrm{d}, \mathrm{x}}$ & $100 \pm 2^{\mathrm{D}, \mathrm{X}}$ \\
\hline B. subtilis & $12 \pm 2^{\mathrm{a}, \mathrm{x}}$ & $100 \pm 4^{\mathrm{A}, \mathrm{X}}$ & $3 \pm 1^{\mathrm{f}, \mathrm{y}}$ & $25 \pm 2^{\mathrm{E}, \mathrm{Y}}$ & $3 \pm 1^{\text {by }}$ & $100 \pm 4^{\mathrm{A}, \mathrm{X}}$ & $12 \pm 2^{\mathrm{e}, \mathrm{x}}$ & $25 \pm 2^{\mathrm{E}, \mathrm{Y}}$ & $3 \pm 1^{\mathrm{by}}$ & $50 \pm 2^{\mathrm{B}, \mathrm{Y}}$ & $50 \pm 1^{\mathrm{d}, \mathrm{x}}$ & $100 \pm 2^{\mathrm{D}, \mathrm{X}}$ \\
\hline M. luteus & $25 \pm 2^{\mathrm{a}, \mathrm{x}}$ & $100 \pm 2^{\mathrm{A}, \mathrm{X}}$ & $2 \pm 1^{\mathrm{e}, \mathrm{y}}$ & $12 \pm 2^{\mathrm{FY}}$ & $25 \pm 4^{\mathrm{a}, \mathrm{x}}$ & $100 \pm 4^{\mathrm{A}, \mathrm{X}}$ & $2 \pm 1^{\mathrm{e}, \mathrm{y}}$ & $25 \pm 2^{\mathrm{E}, \mathrm{Y}}$ & $12 \pm 2^{\mathrm{b}, \mathrm{y}}$ & $50 \pm 1^{\mathrm{B}, \mathrm{Y}}$ & $50 \pm 4^{\mathrm{d}, \mathrm{x}}$ & $100 \pm 4^{\mathrm{D}, \mathrm{X}}$ \\
\hline \multicolumn{13}{|l|}{ Gram-negative } \\
\hline E. coli & $12 \pm 2^{\mathrm{b}, \mathrm{x}}$ & $25 \pm 2^{\mathrm{B}, \mathrm{X}}$ & $6 \pm 2^{e, y}$ & $25 \pm 4^{\mathrm{E}, \mathrm{X}}$ & $12 \pm 2^{\mathrm{b}, \mathrm{X}}$ & $25 \pm 4^{\mathrm{B}, \mathrm{X}}$ & $6 \pm 2^{e, y}$ & $12 \pm 2^{\mathrm{FY}}$ & $25 \pm 1^{\mathrm{a}, \mathrm{x}}$ & $50 \pm 4^{\mathrm{A}, \mathrm{Y}}$ & $25 \pm 2^{\mathrm{d}, \mathrm{x}}$ & $100 \pm 2^{\mathrm{D}, \mathrm{X}}$ \\
\hline K. pneumoniae & $25 \pm 1^{\mathrm{a}}$ & $100 \pm 2^{\mathrm{A}}$ & - & - & $6 \pm 2^{b}$ & $50 \pm 4^{\mathrm{B}}$ & - & - & - & - & - & - \\
\hline S. enteritidis & - & - & $6 \pm 2^{\mathrm{d}}$ & $12 \pm 2^{\mathrm{D}}$ & - & - & $3 \pm 1^{\mathrm{e}}$ & $12 \pm 2^{\mathrm{D}}$ & - & - & - & - \\
\hline
\end{tabular}

MIC and MBC value were expressed in $\mathrm{mg} / \mathrm{mL}$. Values are mean \pm standard deviation of three separate experiments. For each solvent of seeds extracts, values of MIC in the same row followed by a different letter $\left.{ }^{(\mathrm{a}-\mathrm{c}}\right)$ are significantly different $(\mathrm{p}<0.05)$. Results are ranked in ascending order; $\mathrm{a}>\mathrm{b}>\mathrm{c}$. For each solvent of seeds extracts, values of $\mathrm{MBC}$ in the same row followed by a different letter $\left({ }^{\mathrm{A}-\mathrm{C}}\right)$ are significantly different $(\mathrm{p}<0.05)$. Results are ranked in ascending order; $\mathrm{A}>\mathrm{B}>\mathrm{C}$. For each solvent of peels fruits extracts, values of MIC in the same row followed by a different letter $(\mathrm{d}-\mathrm{f})$ are significantly different $(\mathrm{p}<0.05)$. Results are ranked in ascending order; $\mathrm{d}>\mathrm{e}>\mathrm{f}$. For each solvent of peels fruits extracts, values of MBC in the same row followed by a different letter $\left.{ }^{(\mathrm{D}-\mathrm{F}}\right)$ are significantly different $(\mathrm{p}<0.05)$. Results are ranked in ascending order; D $>$ E $>$ F. For each plant organ, values of MIC in same row followed by a different letter $\left({ }^{x, y}\right)$ are significantly different $(\mathrm{p}<0.05)$. Results are ranked in ascending order; $\mathrm{x}>\mathrm{y}$. For each plant organ, values of MBC in same row followed by a different letter $(\mathrm{X}, \mathrm{Y})$ are significantly different $(\mathrm{p}<0.05)$. Results are ranked in ascending order; $\mathrm{X}>\mathrm{Y}$. 
These findings are in accordance with the previous results reporting that acetone is capable to extract antimicrobial compounds from plant materials (Addo-Mensah et al., 2015). The strong antibacterial activity of the extracts against the tested microorganisms was attributed to the presence of high content of polyphenols in seeds and peels fruits extracts.

These data suggest that seeds and peels fruits of E. elaterium have a good potential inhibitor of food spoiling microbial growth and could be a highly effective therapeutic choice for human infections.
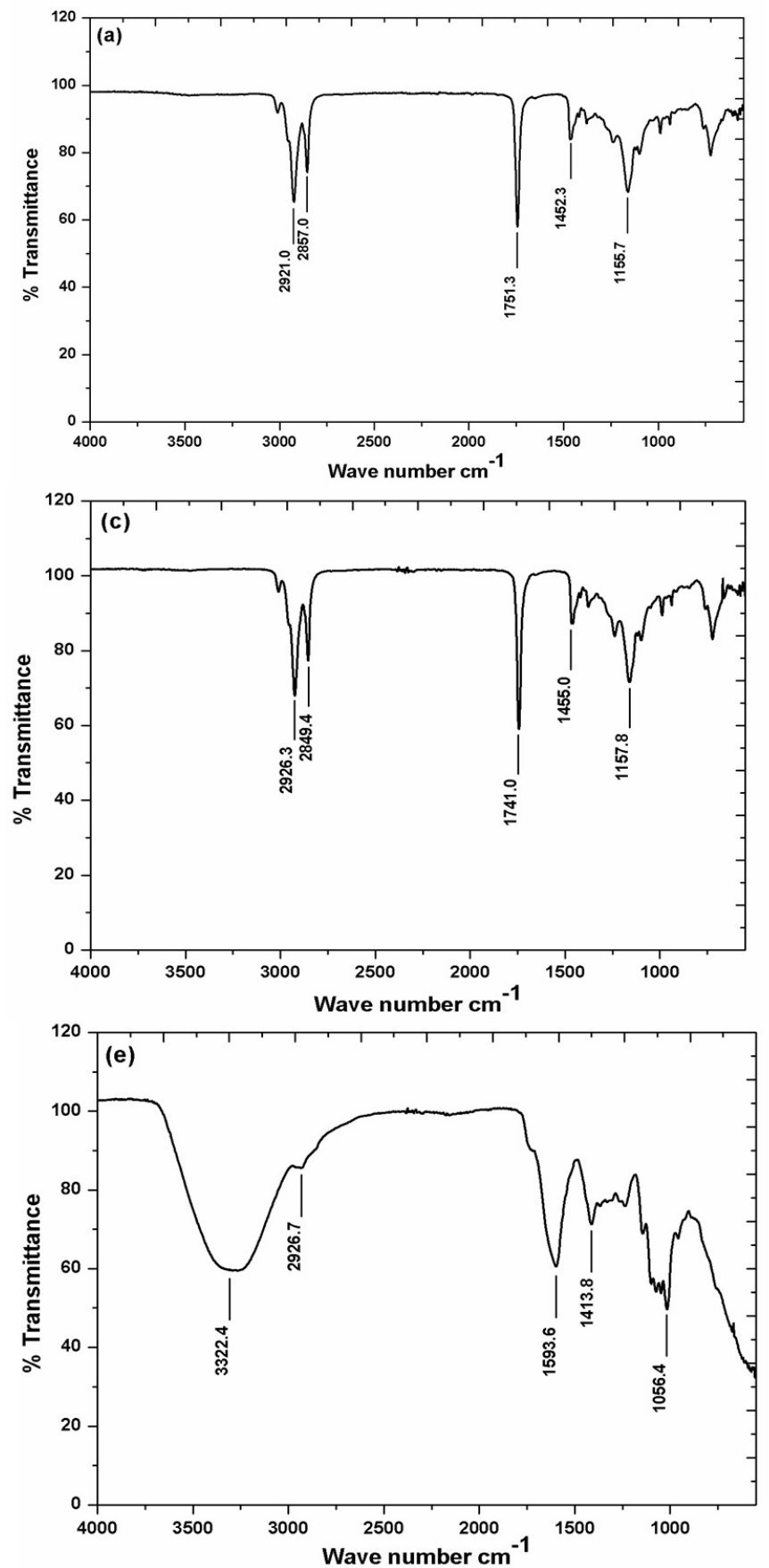

\subsection{FT-IR spectral analysis of extracts}

The FT-IR spectrum has proven to be a valuable tool to identify the functional group of the active components. The FT-IR spectrum profile of various seeds and peels fruits extracts was illustrated in Figure 2. For seeds and peels diethyl ether, acetone and methanol extracts, a characteristic bands occurring at $2921.0 / 2857.0 \mathrm{~cm}^{-1}$ and $2918.6 / 2856.8 \mathrm{~cm}^{-1}$, at $2926.3 / 2849.4 / 2922.6 \mathrm{~cm}^{-1}$ and at $2926.7 / 2932.6 \mathrm{~cm}^{-1}$ respectively, corresponding to the $\mathrm{C}-\mathrm{H}$ symmetric stretching of methylene groups in aliphatic compounds. There is no absorption between
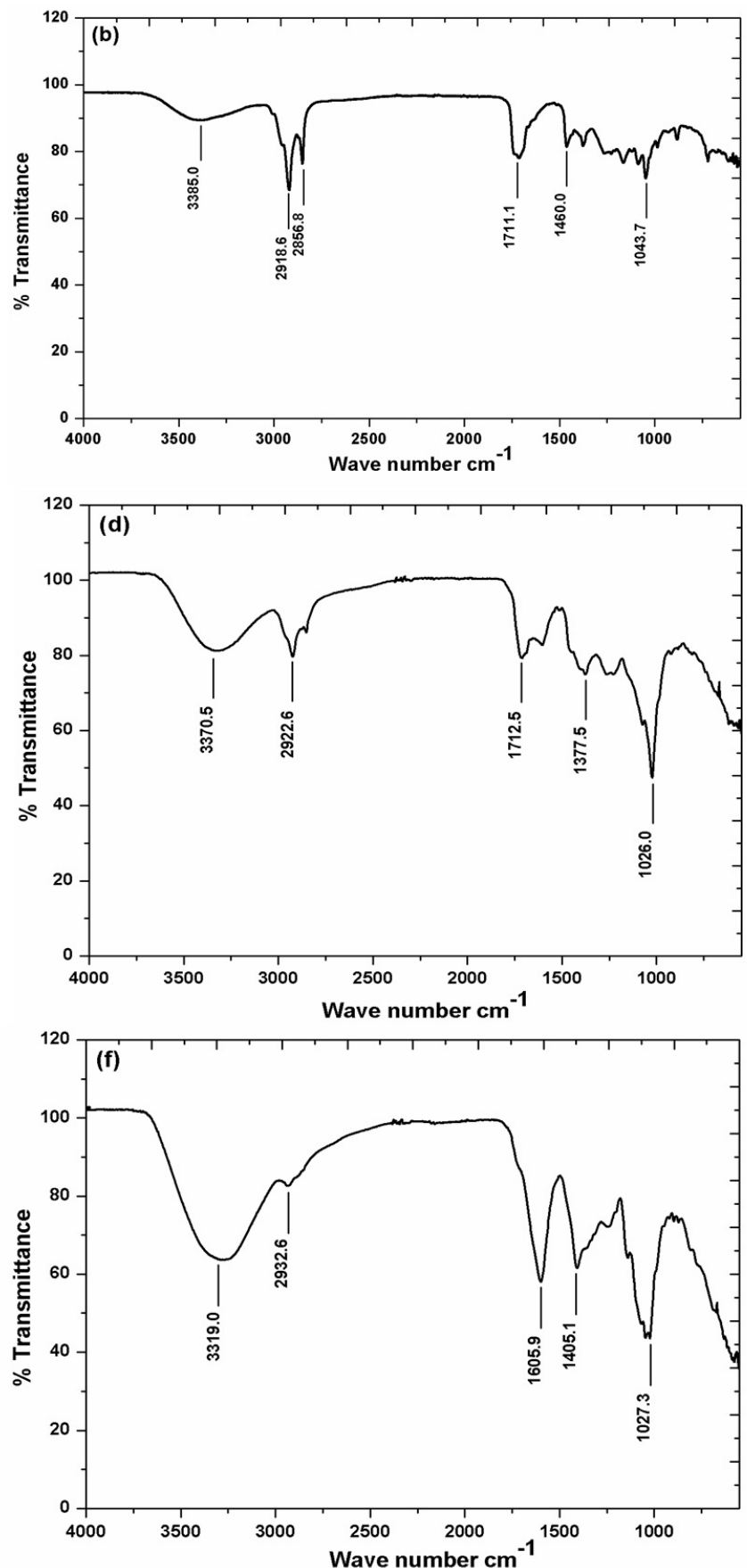

Figure 2. FT-IR spectrum of diethyl ether seeds extract (a); diethyl ether peels fruits extract (b); acetone seeds extract (c); acetone peels fruits extract (d); methanol seeds extract (e) and methanol peels fruits extract (f) of E. elaterium. 
the region $2220-2260 \mathrm{~cm}^{-1}$ indicates that no cyanide groups in all three extracts which means that all extracts not contain any toxic substances. The bands observed in diethyl ether and acetone extracts, respectively at 1751.3 and $1711.1 \mathrm{~cm}^{-1}$, and at 1741.0 and $1712.5 \mathrm{~cm}^{-1}$ are responsible for the stretching vibration of $\mathrm{C}=\mathrm{O}$ group, however no bands are shown for methanol extract. For all peels fruits extracts and for methanol seeds extract, the very strong absorptions observed at $3385.0 / 3370.5 / 3319.0 \mathrm{~cm}^{-1}$ and $3322.4 \mathrm{~cm}^{-1}$ for hydroxyl group $(-\mathrm{OH})$ indicating the presence of withanolides in the sample (Dinan et al., 2001). Only for methanol seeds and peels fruits extracts, the presence of bands at 1593.6 and $1605.9 \mathrm{~cm}^{-1}$ respectively, provide the richness of methanol extract on protein. On the other hand, we noted the presence of many major bands in the spectral range of $1600-600 \mathrm{~cm}^{-1}$ which reflect that some bioactive molecules of significance have been detected in all the extracts with nutraceutical effect and further indicate the presence of withanolides since these frequencies are characteristic of ether, carboxylic acids and esters (Gorinstein et al., 2010). Felhi et al. (2016b) carried out the FT-IR spectral analysis of freeze-dried extract obtained from fruit juice of E. elaterium and reported the presence of characteristic functional groups such as $-\mathrm{OH}$, $\mathrm{C}-\mathrm{O},-\mathrm{C} \equiv \mathrm{C}$ and $\mathrm{C}-\mathrm{H}$ of phenolic compounds, carboxylic acids, alcohols, carbohydrates, and proteins in the plant, that are responsible for various medicinal properties. The various functional groups observed in different extracts reflected the biochemical compositions of E. elaterium. The presence of phytochemical carrying hydroxyl group $(-\mathrm{OH})$ of polyphenolic such as, flavonoids and tannins provide a relative ranking of extracts in term of antioxidant activity.

\section{Conclusions}

This is the first report which evaluates the effects of solvent and plant organ used on various phytochemicals contents from the seeds and peels fruits extracts of E. elaterium. The results showed that the solvent used in extraction affects the yield, total phenolic, total flavonoid, flavonols, condensed tannins, carotenoids contents and their antioxidant and antimicrobial properties in various degrees. The highest contents of phytochemical contents were obtained with methanol extracts. From this study it could be conducted that the tested E. elaterium seeds and peels fruits extracts have potential antioxidant and antibacterial properties. Considering antioxidant properties evaluated via DPPH, ABTS radical scavenging activities and reducing power assay, the better activity was shown, respectively by methanol and acetone extracts of all plant organs. Additionally, the antimicrobial inhibition zone diameters, MIC and MBC values of extracts were determined, and the results showed that the peels fruits extract, such acetone and diethyl ether extract, exhibited the highest antibacterial activity against the Gram-positive bacteria, but no antifungal activity was observed for all extracts. In conclusion, these results have established that seeds and peels fruits of E. elaterium exhibited high in vitro antioxidant and antibacterial activities justifying their usage in folk medicine due to the phytochemical constituents and may be a good candidate for pharmaceutical plant based products and support the usefulness of this plant as food consumers.

\section{References}

Abbassi, F., Ayari, B., Mhamdi, B., \& Toumi, L. (2014). Phenolic contents and antimicrobial activity of squirting cucumber (Ecballium elaterium) extracts against food-borne pathogens. Pakistan Journal of Pharmaceutical Sciences, 27(3), 475-479. PMid:24811804.

Abdel-Hameed, E. S. S. (2009). Total phenolic contents and free radical scavenging activity of certain Egyptian Ficus species leaf samples. Food Chemistry, 114(4), 1271-1277. http://dx.doi.org/10.1016/j. foodchem.2008.11.005.

Addo-Mensah, A., Garcia, G., Maldonado, I. A., Anaya, E., Cadena, G., \& Lee, L. G. (2015). Evaluation of antibacterial activity of Artemisia vulgaris extracts. Research Journal of Medicinal Plants, 9(5), 234-240. http://dx.doi.org/10.3923/rjmp.2015.234.240.

Amensour, M., Sendra, E., Abrini, J., Pérez-Alvarez J. A., and FernándezLópez, J. (2010). Antioxidant activity and total phenolic compounds of myrtle extracts. CyTA: Journal of Food, 8(2), 95-101. http://dx.doi. org/10.1080/19476330903161335.

Ammar, I., Ennouri, M., \& Attia, H. (2015). Phenolic content and antioxidant activity of cactus (Opuntia ficus-indica L.) flowers are modified according to the extraction method. Industrial Crops and Products, 64, 97-104. http://dx.doi.org/10.1016/j.indcrop.2014.11.030.

Arakaki, D. G., Candido, C. J., Silva, A. F. D., Guimarães, R. D. C. A., \& Hiane, D. A. (2016). In vitro and in vivo antioxidant activity of the pulp of Jatobá-do-cerrado. Food Science and Technology (Campinas.), 36(1), 166-170. http://dx.doi.org/10.1590/1678-457X.0084.

Augusto, T. R., Salinas, E. S. S., Alencar, S. M., D’arce, M. A. B. R., Camargo, A. C., \& Vieira, T. M. F. S. (2014). Phenolic compound and antioxidant activity of hydroalcoholic extracts of wild and cultivated murtilla (Ugni molinae Turcz.). Food Science and Technology (Campinas.), 34(4), 667-673. http://dx.doi.org/10.1590/1678-457X.6393.

Bakari, S., Ncir, M., Felhi, S., Hajlaoui, H., Saoudi, M., Gharsallah, N., \& Kadri, A. (2015). Chemical composition and in vitro evaluation of total phenolic, flavonoid, and antioxydant properties of essential oil and solvent extract from the aerial parts of Teucrium polium grown in Tunisia. Food Science and Biotechnology, 24(6), 1943-1949. http:// dx.doi.org/10.1007/s10068-015-0256-z.

Bizid, S., Sabbah, M., Msakni, I., Ben Slimene, B., Mohamed, G., Bouali, R., Abdallah, H. B., \& Abdelli, N. (2014). Cholestatic hepatitis due to Ecballium elaterium ingestion. Clinics and Research in Hepatology and Gastroenterology, 39(5), e61-e63. PMid:25573494. http://dx.doi. org/10.1016/j.clinre.2014.11.004.

Boukef, M. K. (1986). Les plantes dans la médecine traditionnelle tunisienne. Agence de Coopération Culturelle et Technique, 1, 1-350.

Boulekbache-Makhlouf, L., Medouni, L., Medouni-Adrar, S., Arkoub, L., \& Madani, K. (2013). Effect of solvents extraction on phenolic content and antioxidant activity of the byproduct of eggplant. Industrial Crops and Products, 49, 668-674. http://dx.doi.org/10.1016/j. indcrop.2013.06.009.

Daoud, A., Drira, M., Bakari, S., Hfaiedh, N., Mnafgui, K., Kadri, A., \& Gharsallah, N. (2015). Assessment of polyphenol composition, antioxidant and antimicrobial properties of various extracts of Date Palm Pollen (DPP) from two Tunisian cultivars. Arabian Journal of Chemistry, (in press) http://dx.doi.org/10.1016/j.arabjc.2015.07.014.

Dinan, L., Harmatha, J., \& Lafont, R. (2001). Chromatographic procedures for the isolation of plant steroids. Journal of Chromatography, A, 935(1-2), 105-123. PMid:11762770. http://dx.doi.org/10.1016/ S0021-9673(01)00992-X.

El-Gengaihi, S., Abd El-Hamid, S. R., \& Kamel, A. M. (2009). Antiinflammatory effect of some cucurbitaceous plants. Herba Polonica, 55(4), 119-126. Retrieved from http://www.iripz.pl/ 
El-Haci, I. A., \& Bekkara, F. A. (2011). Antioxidant activity of stems and leaves organic fractions of Ecballium elaterium L. Annals of Biological Research, 2(3), 327-332. Retrieved from http://www. scholarsresearchlibrary.com/

Felhi, S., Baccouch, N., Ben Salah, H., Smaoui, S., Allouche, N., Gharsallah, N., \& Kadri, A. (2016a). Nutritional constituents, phytochemical profiles, in vitro antioxidant and antimicrobial properties, and gas chromatography-mass spectrometry analysis of various solvent extracts from grape seeds (Vitis vinifera L.). Food Science and Biotechnology, 25(6), 1537-1544. http://dx.doi.org/10.1007/s10068-016-0238-9.

Felhi, S., Hajlaoui, H., Ncir, M., Bakari, S., Ktari, N., Saoudi, M., Gharsallah, N., \& Kadri, A. (2016b). Nutritional, phytochemical and antioxidant evaluation and FT-IR analysis of freeze dried extracts of Ecballium elaterium fruit juice from three localities. Food Science and Technology (Campinas.), 36(4), 646-655. http://dx.doi. org/10.1590/1678-457x.12916.

Galanakis, C. M., Goulas, V., Tsakona, S., Manganaris, G. A., \& Gekas, V. (2013). A knowledge base for the recovery of natural phenols with different solvents. International Journal of Food Properties, 16(2), 382-396. http://dx.doi.org/10.1080/10942912.2010.522750.

Gorinstein, S., Haruenkit, R., Poovarodom, S., Vearasilp, S., Ruamsuke, P., Namiesnik, J., Leontowicz, M., Leontowicz, H., Suhaj, M., \& Sheng, G. P. (2010). Some analytical assays for the determination of bioactivity of exotic fruits. Phytochemical Analysis, 21(4), 355-362. PMid:20183860. http://dx.doi.org/10.1002/pca.1207.

Goulas, V., Gomez-Caravaca, A. M., Exarchou, V., Gerothanassis, I. P., Segura-Carretero, A., \& Gutiérrez, A. F. (2012). Exploring the antioxidant potential of Teucrium polium extracts by HPLC-SPENMR and on-line radical-scavenging activity detection. LWT-Food Science and Technology, 46(1), 104-109. http://dx.doi.org/10.1016/j. lwt.2011.10.019.

Greige-Gerges, H., Khalil, R. A., Mansour, E. A., Magdalou, J., Chahine, R., \& Ouaini, N. (2007). Cucurbitacins from Ecballium elaterium Juice Increase the Binding of Bilirubin and Ibuprofen to Albumin in Human Plasma. Chemico-Biological Interactions, 169(1), 53-62. PMid:17601519. http://dx.doi.org/10.1016/j.cbi.2007.05.003.

Janakat, S., Al-Nabulsi, A. A. R., Allehdan, S., Olaimat, A. N., \& Holley, R. A. (2015). Antimicrobial activity of amurca (olive oil lees) extract against selected foodborne pathogens. Food Science and Technology (Campinas.), 35(2), 259-265. http://dx.doi.org/10.1590/1678-457X.6508.

Kadri, A., Zarai, Z., Ben Chobba, I., Gharsallah, N., Damak, M., \& Bekir, A. (2011). Chemical composition and in vitro antioxidant activities of Thymelaea hirsuta L. essential oil from Tunisia. African Journal of Biotechnology, 10(15), 2930-2935. http://dx.doi.org/10.5897/ AJB11.028.

Latté, K. P. (2009). Ecballium elaterium (L.) a rich portrait of a medicinal plant. Zeitschrift fur Phytotherapie, 30(3), 148-154. http://dx.doi. org/10.1055/s-0029-1231085.

Maryott, A. A., \& Smith, E. R. (1951). Table of dielectric constants of pure liquids (Vol. 514, pp. 1-44). Washington, D.C.: U.S. Government Publishing Office.

Mazokopakis, E. E., Karefilakis, C. M., \& Starakis, I. K. (2009). The safety and efficacy of the fruit juice of Ecballium elaterium in the treatment of acute rhinosinusitis. Journal of Alternative and Complementary Medicine (New York, N.Y.), 15(12), 1273-1274. PMid:19958105. http://dx.doi.org/10.1089/acm.2009.0241.

Naczk, M., \& Shahidi, F. (2004). Extraction and analysis of phenolics in food. Journal of Chromatography, A, 1054(1-2), 95-111. PMid:15553136. http://dx.doi.org/10.1016/S0021-9673(04)01409-8.
Naima, R., Oumam, M., Hannache, H., Sesbou, A., Charrier, B., Pizzi, A., \& Charrier-El Bouhtoury, F. (2015). Comparison of the impact of different extraction methods on polyphenols yields and tannins extracted from Moroccan Acacia mollissima barks. Industrial Crops and Products, 70, 245-252. http://dx.doi.org/10.1016/j. indcrop.2015.03.016.

Nguyen, V. T., Bowyer, M. C., Vuong, Q. V., Altena, I. A. V., \& Scarlett, C. J. (2015). Phytochemicals and antioxidant capacity of Xao tam phan (Paramignya trimera) root as affected by various solvents and extraction methods. Industrial Crops and Products, 67, 192-200. http://dx.doi.org/10.1016/j.indcrop.2015.01.051.

Re, R., Pellegrini, N., Proteggente, A. E., Pannala, A., Yang, M., \& Rice-Evans, C. (1999). Antioxidant activity applying an improved ABTS radical cation decolourization assay. Free Radical Biology \& Medicine, 26(9-10), 1231-1237. PMid:10381194. http://dx.doi. org/10.1016/S0891-5849(98)00315-3.

Rodríguez-Rojo, S., Visentin, A., Maestri, D., \& Cocero, M. J. (2012). Assisted extraction of rosemary antioxidants with green solvents. Journal of Food Engineering, 109(1), 98-103. http://dx.doi.org/10.1016/j. jfoodeng.2011.09.029.

Sahu, R. K., Kar, M., \& Routray, R. (2013). DPPH free radical scavenging activity of some leafy vegetables used by Tribals of Odisha, India. Journal of Medicinal Plants Studies, 1(4), 21-27. Retrieved from http://www.plantsjournal.com/

Salhab, A. S. (2013). Human exposure to Ecballium elaterium fruit juice: fatal toxicity and possible remedy. Pharmacology \& Pharmacy, 4(5), 447-450. http://dx.doi.org/10.4236/pp.2013.45064.

Sargin, S. A., Akcicek, E., \& Selvi, S. (2013). An ethnobotanical study of medicinal plants used by the local people of Alaşehir (Manisa) in Turkey. Journal of Ethnopharmacology, 150(3), 860-874. PMid:24126062. http://dx.doi.org/10.1016/j.jep.2013.09.040.

Sasmakov, S. A., Putieva, Z. M., Azimova, S. S., \& Lindequist, U. (2012). In vitro screening of the cytotoxic, antibacterial and antioxidant activities of some Uzbek plants used in folk medicine. Asian Journal of Traditional Medicines, 7, 75-80.

Silva, C. P. D., Sousa, M. S. B., Siguemoto, É. S., Soares, R. A. M., \& Arêas, J. A. G. (2014). Chemical composition and antioxidant activity of jatobá-do-cerrado (Hymenaea stigonocarpa Mart.) flour. Food Science and Technology (Campinas.), 34(3), 597-603. http://dx.doi. org/10.1590/1678-457x.6405.

Sripad, G., Prakash, V., \& Rao, M. S. N. (1982). Extrability of polyphenols of sunflower seed in various solvents. Journal of Biosciences, 4(2), 145-152. http://dx.doi.org/10.1007/BF02702723.

Suárez-Jiménez, G. M., Robles-Sánches, R. M., Yépiz-Plascencia, G., Burgos-Hernández, A., \& Ezquerra-Brauer, J. M. (2015). In vitro antioxidant, antimutagenic and antiproliferative activities of collagen hydrolysates of jumbo squid (Dosidicus gigas) byproducts. Food Science and Technology (Campinas.), 35(3), 421-427. http://dx.doi. org/10.1590/1678-457X.6658.

Sun, B., Richardo-da-Silvia, J. M., \& Spranger, I. (1998). Critical factors of vanillin assay for catechin and proanthocyanidins. Journal of Agricultural and Food Chemistry, 46(10), 4267-4274. http://dx.doi. org/10.1021/jf980366j.

Talcott, S. T., \& Howard, L. R. (1999). Phenolic autoxidation is responsible for color degradation in processed carrot puree. Journal of Agricultural and Food Chemistry, 47(5), 2109-2115. PMid:10552504. http:// dx.doi.org/10.1021/jf981134n. 
Touihri, I., Kallech-Ziri, O., Boulila, A., Fatnassi, S., Marrakchi, N., Luis, J., \& Hanchi, B. (2015). Ecballium elaterium (L.) A. Rich. seed oil: Chemical composition and antiproliferative effect on human colonic adenocarcinoma and fibrosarcoma cancer cell lines. Arabian Journal of Chemistry. In press. http://dx.doi.org/10.1016/j.arabjc.2015.02.023.
Zarai, Z., Ben Chobba, I., Mansour, R. B., Békir, A., Gharsallah, N., \& Kadri, A. (2012). Essential oil of the leaves of Ricinus communis L.: In vitro cytotoxicity and antimicrobial properties. Lipids in Health and Disease, 11(1), 102. PMid:22888805. http://dx.doi. org/10.1186/1476-511X-11-102. 